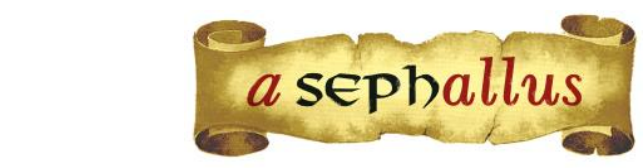

Revista aSEPHallus de Orientação Lacaniana

Núcleo Sephora de Pesquisa sobre o Moderno e o Contemporâneo

ISSN $1809-709$ X

\title{
0 rosto carrancudo da guerra tem as rugas suavizadas ${ }^{1}$
}

Cleyton Andrade

Psicanalista

Membro da EBP e da AMP

Professor do Programa de Pós-Graduação em Psicologia da Universidade Federal de Alagoas

Autor do livro Lacan chinês - Poesia, Ideograma e Caligrafia Chinesa de uma Psicanálise

10 lugar no Prêmio Jabuti na categoria Psicologia, Psicanálise e Comportamento, em 2016

E-mail: cleyton.andrade@ip.ufal.br

Resumo: O texto aborda alguns aspectos das representações sociais, políticas e subjetivas da violência. Formas subjetivas e subjetiváveis da incidência da violência no corpo próprio, no corpo social e político. Com isso procura indicar como ponto de investigação que o encontro dissimétrico entre corpos e entre sujeitos, políticos ou não, ao invés de ser a base para discursos jurídicos, do Direito e de políticas da igualdade, pode na verdade, indicar práticas de dominação e violência, inclusive inscritas no campo da lei e da norma. Em outras palavras, apontar como o discurso do Outro não apenas produz o corpo da histérica, mas corpos que se tornam alvo de políticas públicas de confronto com um inimigo.

Palavras-chave: Psicanálise; Violência; Política.

La guerre au visage renfrogne a aplani son front charge de rides : Le texte aborde certains aspects des représentations sociales, politiques et subjectives de la violence. Formes subjectives et subjectivables de l'incidence de la violence dans le corps propre, dans le corps social et politique. Recherche à indiquer comme point d'investigation que la rencontre dissemblable entre corps et entre sujets, politiques ou non, plutôt que d'être la base de discours juridiques, de lois et de politiques d'égalité, peut en réalité indiquer des pratiques de domination et de violence y compris, inscrit dans le domaine du droit et de la norme. C'est à dire, indiquer comment le discours de l'Autre ne produit pas seulement le corps de l'hystérique, mais des corps qui deviennent la cible de politiques publiques de confrontation avec un ennemi.

Mots-clés: Psychanalyse; Violence; Politique.

Grim-faced war hath smoothed his wrinkled front: The text addresses some aspects of the social, political and subjective representations of violence. Subjective and subjectivable forms of the incidence of violence in the body itself, in the social and political body. It seeks to indicate as a point of investigation that the assymetrical encounter between bodies and subjects, political or not, rather than being the basis for legal discourses, law and equality political, may actually indicate practices of domination and violence, including inscribed in the field of law and the norm. In other words, to point out how the Other's discourse not only produces the body of the hysteric, but bodies that become the target of public political of confrontation with an enemy.

Keywords: Psychoanalysis; Violence; Politics. 


\section{0 rosto carrancudo da guerra tem as rugas suavizadas}

\section{Cleyton Andrade}

Por volta de abril de 1865, logo após receber a notícia do assassinato do presidente norte americano Abraham Lincoln, Charles Holmes se põe a escrever uma carta para a sua amada, a quem, antes de vir a se tornar sua esposa, ainda era alvo dos cortejos deste distinto cidadão. A carta não condizia com os movimentos de corte e sedução. Ao contrário, ela estava tomada por uma raiva que não lhe era típica e de uma "ortografia e pontuação um tanto trôpegas não ficaram melhores com tais sentimentos impossíveis de manejar" (Gay, 1995, p. 135). Em suas palavras, citadas por Peter Gay (1995), "Não sei como dedicar ao agradável dever de escrever para você hoje" (p. 135), e continua Gay:

Sua sede de vingança, reconhecia, não deixava nenhum espaço para a ação de Eros. 'A terrível aflição que caiu tão subitamente sobre nosso infeliz país a tal ponto enche e monopoliza meus pensamentos que não sou capaz do doce intercurso do amor. Minha alma está cheia de dor e amargura e ódio e vingança'. (p. 135)

Holmes não era um homem que nutria ódio, desafeto ou hostilidade, nem mesmo durante sua participação na Guerra Civil norte-americana. Seus modos, segundo Peter Gay, eram afetuosos e líricos. Contudo, o assassinato do presidente Lincoln havia expulsado os anjos da piedade e perdão. Ainda na carta, Holmes dizia:

E tem um estranho lá escuro desassossegado e implacável que eu lhe dou as boas-vindas com todo o ardor sim com todo o afeto de um Amante por sua escolhida e sob seu comando eu coloco minha Alma e coração e forças até que chegue o dia em que não reste um réptil venenoso de toda a ninhada que ouse mostrar a cabeça. [...] Onde fui piedoso serei impiedoso onde em minha limitada esfera e capacidade aconselhei e exerci a Piedade eu na medida de tal esfera e capacidade aconselharei e exercitarei uma guerra vingativa e sem quartel não conhecerei distinção entre traidores em casa ou no campo eu trabalharei pelo desconforto e ruína de ambos eu não perderei nenhuma oportunidade de fazer-lhes mal [...] esperarei por sua morte e me alegrarei em seus túmulos. (Gay, 1995, p. 135-136) Tal trecho apresenta inegável semelhança com as palavras iniciais de Ricardo III, de Shakespeare (1995):

Mas eu, que não fui talhado para as habilidades esportivas, nem para cortejar um espelho amoroso; que, grosseiramente feito e sem a majestade do amor para pavonear-me diante de uma ninfa de lascivos meneios; eu, privado dessa bela proporção, desprovido de todo encanto pela pérfida natureza; disforme, inacabado, enviada por ela antes do tempo para esse mundo dos vivos; terminado pela metade e isso tão imperfeitamente e fora de moda que os cães ladram para mim quando paro perto deles, pois bem, eu, neste tempo de serena e amolecedora paz, não acho delícia em passar o tempo, exceto espiar minha 
sombra no sol e dissertar sobre minha deformidade! E assim, já que não posso mostrar-me como amante, para entreter esses belos dias de galanteria, resolvi portar-me como vilão e odiar os frívolos prazeres deste tempo. (p. 580)

\section{0 rosto carrancudo da guerra e as rugas de amor}

A distinção entre Ricardo III e Charles Holmes não decorre do espaço temporal entre eles, de aproximadamente dois séculos, nem da distinção entre a ficção e a realidade. A convergência é mais clara e imediata do que a dessemelhança. Ambos são tomados pela cólera, pelo ódio e uma inabalável sede de vingança. Contudo, se o fundamento de um parte, em primeiro lugar, de sua imperfeição, sob a castração inscrita sobre seu corpo autorizando-o a se portar como uma exceção, e também devido à sua impotência frente ao outro sexo e às questões do amor; o outro não é atingido por nenhuma dessas experiências. Ele está inscrito no campo do amor e da sedução, não se porta como uma exceção, e talvez, quem sabe, como um privilegiado. Ricardo III é ainda mais dessemelhante, pois sua vilania toma formas empíricas que perturbam de fato os tempos de paz. Ao passo que Holmes, à semelhança de Hamlet, se vê incapaz de vingar a morte de seu presidente diretamente sobre o corpo do assassino, e, ao invés disso, despeja seu ódio sobre sua amada, não de Ofélia, mas de Annie, sua futura esposa. O corpo que recebe seu golpe é o da folha antes em branco.

Tão inacabada quanto começou, esta carta de ódio se interrompe. Envergonhado pelo seu acesso, mas nem tanto a ponto de não enviar a carta (Gay, 1995), Holmes pega outra folha e começa uma nova carta como era de costume: "Minha querida Annie". Nessa ele retorna ao seu semblante usual. Segundo Gay (1995), a notícia sobre a morte do presidente havia dado dois choques em Holmes. Um pela dor da perda; e outro pela selvageria de sua reação.

A vilania a que se propõe Ricardo III é de uma identificação a um semblante sob a marca de uma positividade, enquanto a selvageria de Holmes é um golpe sentido por ele mesmo pela desconformidade com a imagem que tinha de si próprio. Dizia mais da irrupção não de uma animalidade da natureza, mas sim de uma negatividade inscrita no cerne da própria razão. Vale destacar, mesmo que por ora ainda prematuramente, que a violência em jogo seja em Ricardo III, seja em Charles Holmes, ou Hamlet, ganha contornos mais complexos se introduzirmos Otelo.

\section{Um corpo produzido pelo discurso do Outro}

Numa cena, após ser mais uma vez tomado pelos significantes, sentidos e significações de Iago acerca de Desdêmona, Otelo sofre com um momento de ausência e contorções semelhantes a uma convulsão ou sintomas de conversão. O diálogo que precede esse acontecimento de corpo é particularmente ilustrativo. Iago descrevia um encontro entre Cássio e Desdêmona. Otelo ao ouvir Iago dizendo to lie, que significa tanto mentir quanto deitar, escuta, a partir de significações produzidas anteriormente por Iago, deitar. E interroga de imediato lie with her? Deitar com ela? E 
Iago responde: with her, on her, what you will/com ela, sobre ou em cima dela, como quiser. Vale dizer que lie on her pode significar tanto mentir sobre ela quanto deitar sobre ela, e lie with her pode significar tanto mentir com ela ou deitar com ela. Diante desta equivocidade do significante a violência de Otelo antes mesmo de se voltar para o final dramático da peça, evidencia a incidência de uma violência e culpa, voltados sobre o corpo próprio sob a forma de um sofrimento psíquico.

As emoções violentas não fazem parte de um arsenal instintivo que parte de uma natureza que por vezes se liberta das restrições e amarras civilizadas. 0 par tristeza e agressividade são constitutivos da civilização. Se a vingança de Ricardo III se volta contra todos e contra a paz do reino, a de Holmes se volta contra sua amada e encontra seu limite no papel da carta, a de Otelo se volta primeiro contra ele mesmo. A censura à heteroagressão tem seu preço, muito embora sua libertação não se traduza em nenhuma forma de saúde mental.

\section{Violência e propriedade}

A censura à violência individual divide seu leito em plena cultura respeitável do século XIX com uma conivência e adesão a diversas formas de agressões punitivas. Por exemplo, na Inglaterra mercantil daquele século, as punições draconianas são aplicadas a todos aqueles que atentassem contra a propriedade privada, ao mesmo tempo em que se defende os Direitos Humanos enquanto um dos pilares da liberdade, da cidadania e da democracia. O direito à propriedade, por vezes, parece ser mais inalienável do que os direitos do homem, sobretudo se por homem entendemos cidadão e por extensão, produto e criação de princípios erguidos em torno de uma economia e comércio de propriedades.

A busca iluminada e iluminista da razão não se fazia de maneira menos obscura, de modo que aplacasse uma opacidade e divisão da própria razão. Vale lembrar que me refiro à Inglaterra, França, Alemanha, à Viena vitoriana, à Europa, enfim. Todos são lugares e modelos de cultura e progresso civilizatório, e não dos aborígenes australianos ou pireneus. É nessa Europa civilizada, civilizatória e colonialista que a divisão melhor pode ser observada.

No final do século XVII a lista de crimes capitais na Inglaterra continha 60 itens. Depois de aproximadamente 75 anos, eles passaram para 160 e, em 1820, chegaram a cerca de 220. Pode parecer, mas, apesar das semelhanças, não me refiro às edições do DSM. Começam a surgir teses a respeito da distinção entre crimes vindos das classes inferiores rurais e das classes trabalhadoras urbanas, ao mesmo tempo em que uma boa parcela da população passava a aceitar e dar as boas vindas à pena de morte, inclusive para crimes menores. Afinal, para muitos, o Estado não poderia admitir a violência à propriedade privada sem punir com a morte. Na Inglaterra mercantil, tanto os defensores das punições draconianas quanto seus opositores eram da classe média. Eram bons burgueses.

A solução já fora apontada por Foucault (1979), que chamava a atenção para uma prática hegemônica da modernidade. Esta encontrou na prescrição normativa da distinção entre o normal 
e o patológico uma forma de praticar um poder disciplinar e constituir subjetividades. Pôde-se nomear uma violência cujo fundamento estaria no excesso, na desrazão, nos instintos incontroláveis, e outra cujo fundamento seria o ordenamento da razão, o Bem e, obviamente, o ordenamento jurídico. De um lado a violência do Estado e de outro a violência do indivíduo, com a sensível diferença de que a primeira seria o exercício da Lei enquanto a segunda seria inscrita como ilegal. O que separaria a ilegalidade de Robin Hood e a legalidade da cobrança excessiva de impostos da precarização do campesinato é que a Lei que traça esse limite tem autor definido.

As leis expressam sob a forma do Direito as condições e costumes daquele que legisla - e isso pode ser dito tanto com Marx (2017) quanto com Freud (2010[1932]). Nesse sentido, seria possível recorrer ao Estado Democrático de Direito como fundamento e justificativa para violências legais ou legalizáveis. O que o século XIX elegeu como marco regulatório para a distinção entre violência normal e patológica foram argumentos valorativos e, portanto, não universais, posto que eram valores prescritos pela classe média. Dizendo de outro modo, eram universais teóricos e especulativos, como princípios ideológicos e não como função aplicável de fato. Tal como Paulo de Tarso poderia dizer que no Reino de Deus todos eram iguais perante a Deus, cidadãos do Céu, mas no mundo romano, perante Roma, a única igualdade seria aquela que se aplica aos romanos. $\mathrm{O}$ universal em Roma era o universal romano. Tratava-se de uma escala valorativa que prescrevia uma violência como excesso, ilegal ou patológica e outra como necessária, sensata, além de pautada frequentemente como álibi para violências que se não eram legítimas, pelo menos seriam legais.

A fantasia da queda do homem, vítima de uma punição, poderia ser amparada pelo livro do Gênesis, pelo medo do inferno, na leitura vitoriana da Bíblia "como uma saga terrível de desobediência e punição" (Gay, 1995, p. 138). Importa menos a figura e mais a estética que se repetia entre transgressão e culpa, desobediência e punição, crime e castigo. Afinal, seja como for, eram duas faces da mesma moeda. Importa menos se o discurso se pauta na Bíblia como modelo estético de uma moral, e mais pelo destaque muito bem capturado por Freud (2012[1912-1913]): o de um processo civilizatório que, por ser constituído por uma transgressão mítica e uma culpa, por uma perda fundamental e fundante, não tem como saldar esse descompasso, e por isso não tem como prescindir da barbárie. Ela não é o estágio que precede a civilização como um estado de natureza pré-cultura. A barbárie não é uma civilização a menos, ainda não realizada. A barbárie é o saldo irredutível de todo processo civilizatório. Uma barbárie que pode se expressar de modo heterônomo como violência social ou se expressar sob a forma de um sofrimento ou adoecimento psíquico.

Um dos legados do Iluminismo aos vitorianos foi o debate sobre a natureza humana. Ele se agigantava na grande tela das explicações racionais para o castigo, à medida que os reformadores enfrentavam a questão sensível da vingança como álibi da agressão. Quase todos os especialistas do século XIX em crime e castigo, uma tribo que crescia 
rapidamente, concordavam em que o impulso que trazia mais dificuldades nas tentativas de resgate da natureza humana das consequências da belicosidade inata era o anseio de vingança. (Gay, 1995, p. 146)

O ponto de convergência recaía nas implicações legais e psicológicas deste traço indelével. Havia um inegável apetite de vingança. A natureza humana que fora responsabilizada pela barbárie patológica de uns, passa a ser o fundamento ontológico para a justificativa de uma sede de vingança como um produto e como uma doença crônica do corpo social (Gay, 1995). Do corpo social para o corpo da histérica é apenas um passo. E neste caso, os poetas e artistas de fato antecipam o psicanalista.

Como vimos, Otelo aponta para as coordenadas de como o corpo pode ser afetado pelo discurso do Outro social. Ao mesmo tempo ele nos oferece um entendimento do porquê para Freud não havia diferença entre psicologia individual e psicologia social. Não porque faltaria a esta última os marcadores suficientes para situar claramente seu objeto, mas sim porque falta à primeira um estatuto seguro. Shakespeare nos mostra como se torna difícil dizer que o corpo de Otelo pertenceria de fato a ele. A culpa pelo seu casamento clandestino e descoberto pelo pai de Desdemona o invade. Sobretudo pelo discurso sobre a traição da amada - primeiro como filha traidora do pai e depois fatalmente como mulher que também trairá. A esse discurso feito pelo pai de Desdemona se alia a outro discurso, o de Iago. Essa sobreposição de significantes e signos de traição demonstraria um modo de gozo intratável e, por isso mesmo, desenharia um destino traçado de traições. Ou seja, as palavras de Iago se valeram de uma outra cena já forjada pelo discurso do Outro. Tudo isso nos mostra que o corpo do mouro pouco lhe pertence, uma vez que habitado pelo discurso, é quase uma propriedade do Outro da linguagem. Como poderia haver psicologia individual se mal encontramos qualquer coisa em Otelo que possamos reconhecer e chamar, a rigor, de indivíduo? Tal como é o corpo de Otelo, é o corpo da histérica.

Há um entrelaçamento tal entre transgressão e culpa, crime e castigo, agressão e melancolia, história, discurso, corpo e sofrimento que não bastou a poesia e literatura oferecerem seu contorno, foi preciso oferecer a Otelos e Anas uma escuta que inscrevesse de vez no campo social seu discurso inaudito. Doutores de loucos, psiquiatras e alienistas, na década de 1860 diziam que "se herdava a insanidade, a disposição à degeneração e a tendência para o crime, assim como se herdava a cor da pele" (Gay, 1995, p. 161). Um corpo seria o herdeiro de marcadores biológicos de tendências à degeneração e ao crime.

Uma das viradas de Freud foi fazer do corpo da histérica um herdeiro do discurso do Outro, de uma história de desejos de desejos, deslocando a cena da degeneração moral para uma aliança perturbadora entre, de um lado, crime e castigo, e do outro, o sexual. Os marcadores deixam de ser biológicos para se tornarem as difíceis relações entre o discurso, a linguagem e suas diferentes formas de negatividade, bem como de outras formas de positividades. A herança que toma o corpo é tanto a do discurso, quanto daquilo que não pode encontrar uma representação 
discursiva. Essa negatividade, contudo, não deixa de produzir marcas neste corpo. Um dos modos de compreender a negatividade em jogo no sexual é tornar pensável a existência de inscrições ilegíveis tatuadas no corpo a ponto de impedirem uma historicidade sem hiatos.

Freud força um deslocamento da sala de interrogatório da criminologia de Lombroso, não para o confessionário da pastoral católica como queria Foucault, mas para o relato de uma memória incerta e vacilante que, quando produz histórias, estas não passam de fragmentos de um discurso que nem mesmo encontra no eu a normatividade que the seria própria. Traços heterônomos do discurso do Outro que portam em si mesmos uma impossibilidade de confissão, uma vez que seriam despossuídos de sua propriedade. São no máximo um testemunho. Trata-se, então, do acolhimento de uma forma de relato que admite que o corpo conte a história impronunciável dos circuitos da pulsão.

\section{Experiência trágica e violência}

Em Totem e tabu, Freud (1912-1913/2012) demonstra como crime e castigo, desejo de transgressão e culpa, não são desvios de um processo civilizatório, mas sim sua condição de possibilidade. Freud, no início da década de 1890, ao analisar a sintomatologia histérica, prestou uma larga homenagem ao impacto da experiência sobre a mente. Em outras palavras, sobre o impacto do social sobre o pensamento e o corpo. Não sem motivo, que a primeira teoria da neurose já tratava, a despeito do destino que Ihe foi reservado posteriormente, em linhas gerais, de uma modalidade de encontro traumático decorrente de um enfrentamento com o Outro social sob o registro de uma cena de violência. Mais especificamente, de uma sedução sofrida sob os marcadores da violência, na infância. $O$ próprio fato de ser um encontro dessimétrico entre uma criança e figuras de alteridade que podem ser nomeadas de modo simplificado como "um adulto", delineiam as bases de uma agressão. Portanto, apesar de ter sido abandonada, a teoria da sedução salienta um entrelaçamento desconfortável entre violência, sexualidade, desejo e subjetividade.

Se a dimensão moral da agressão de caráter sexual por parte de um adulto sobre uma criança, que hoje chamamos de assédio, é deixada de lado, apesar de ainda hoje ser um problema real muito mais frequente do que se possa imaginar, uma outra dimensão trágica da violência ocupa esse espaço. A desmontagem de uma teoria que se sustentava sobre marcadores de uma historicidade empírica que colocava a criança como objeto e vítima de uma sedução, cede seu lugar para, pelo menos, dois modelos de inteligibilidade que são marcados pela dimensão trágica. Seja na teoria da fantasia, seja no modelo edípico, é o elemento trágico que salta aos olhos. A síntese impossível entre os lugares de sujeito dividido e de objeto na fantasia ou do modelo estético do mito de Édipo testemunham isso. Não é à toa que dentre todas as versões desse mito disponíveis e ao alcance de Freud, ele opta pela tragédia de Sófocles. Quero destacar com isto que o elemento trágico enquanto uma síntese impossível de ser feita é essencial para a inteligibilidade 
e a definição de seu alcance. Desejo, aversão, amor, ódio, transgressão, culpa, não são vetores ontológicos. Eles implicam numa ética na qual se portam como eixos inconciliáveis, embora coexistam.

O trágico, e não o incesto, é o ponto essencial no Édipo. É exatamente aquilo que tem de trágico que garante uma racionalidade que não salva o pathos pelo saber, nem quita o não-saber com o logos. O trágico é a síntese impossível que impõe a compreensão de que há pathos no logos, de que há não-saber no saber. E que o sujeito, tal como um herói trágico, paga com seu próprio corpo uma vez que não tem como se eximir da culpa. Que não tem como se livrar do regime de invisibilidade que se impõe sobre o plano da visibilidade. Que se vê incapaz de se livrar do peso que Ihe recai sobre os ombros ou face, de que a transparência ou luz fletida sobre a razão não o resguarda da opacidade ou anamorfose.

Além disso, a agressão se anuncia como aquilo que será elevado, nas teorias sociais freudianas, ao mesmo patamar moral da libido, sem fazer disso um elogio à agressão, mas sim uma advertência (Gay, 1995). Vale destacar que no espaço social e político o medo vem, historicamente, ganhando um papel relevante. Um dos problemas disto é que o medo de uma morte violenta, em termos políticos, pode abrir portas para um governo absoluto.

Coube a Locke a conversão da filosofia política numa defesa da propriedade (Ribeiro, 2004). A questão se torna ainda mais complexa à medida em que a vida, ao ser assimilada à propriedade, se mostraria sujeita, susceptível de abalos, e com isso passível de perda. O homem como proprietário de si mesmo teme o outro porque é este outro que pode despossuí-lo de si. 0 medo tornado programa de governo pode assumir uma roupagem que incita a todos a se armarem até os dentes para defenderem sua propriedade, leia-se, sua casa, sua família e a si próprio, para impedir que o outro venha requerer a propriedade. O "isto é meu!" que pode partir de todos, torna estéril o Direito. Se para Hobbes (Ribeiro, 2004) é isso que abrirá caminho para o soberano, haveria nos dias de hoje um novo tipo de soberano? Seria possível pensar a figura de um soberano que promete autorizar e legitimar a guerra de todos contra todos?

A novidade aí não se refere ao medo da violência do outro que se apropriaria da minha propriedade, tanto de minha vida quanto de meu modo de vida, mas sim de uma suspensão do direito, do discurso jurídico, do Estado, para estimular e legitimar como virtude a guerra contra meu vizinho. De um Estado que caberia moderar a violência a fim de preservar da propriedade daquele que tem, a um tipo de soberania que transfere ao proprietário a posse e o porte do direito de se defender do que quer que seja. A princípio, o vizinho parece ser o ladrão, o marginal, enfim, o homem mau que rouba seus bens. Contudo, logo depois será o negro pobre, depois o pobre, 0 homoafetivo, o adepto do poliamor, a mulher, o povo, aquele que perturba o princípio igualitário. A verdade da guerra armada contra o homem mau não é que ele ameaça roubar seus bens; ela passa a ser aquela contra quem ameaça a sua propriedade, ou seja, seu ideal de família, seu modo de vida, ameaça sua sexualidade, seu gênero, suas certezas falocêntricas. 
Com isso o "vizinho" do homem de bem que ameaça a sua propriedade, logo poderá estar ao seu lado no elevador, morando na mesma casa ou até mesmo dormindo ao seu lado. O limite poderá se tornar cada vez mais opaco. Os vizinhos hermanos venezuelanos se tornarão invasores. Aquilo que era uma diversidade cultural que animava comércios e relações de regiões fronteiriças poderá se tornar o espaço de encontro com um gozo insuportável e ameaçador. As venezuelanas já são chamadas, em alguns lugares no norte do Brasil, de ochenta (fazendo menção ao valor, oitenta reais, que seria cobrado por um programa sexual) como um modo de escancarar a despossessão não só de seu país, seu trabalho, sua família, sua dignidade, mas também, e, sobretudo, de seu corpo. Ou oito ou ochenta é o lapso de tempo que converte a possessão em despossessão, o sexo em violência sem uma gota de sangue, sem um mero golpe de mão a ser desferido.

É a violência que a um só golpe desmascara os direitos humanos, pois, como diria Hanna Arendt e Agamben (2015), bastou que o refugiado fosse despossuído de sua nação para também ser despossuído de sua humanidade e de seus direitos. Esse fenômeno denuncia que o fundamento dos Direitos Humanos não é nem o Direito nem a Humanidade, é a nação, o território, como metáfora da propriedade. Eles seriam uma espécie de condensação dos elementos mínimos para a construção de uma racionalidade de Estado, àquela época, chamado burguês.

\section{A antessala das considerações finais}

Há uma violência que não aparece nas estatísticas da segurança pública e que nenhuma bala, nem de prata, será capaz de por fim. Essa violência não provém do homem mau, ela pode vir do homem de bem. Assim como outras formas de violência, estas sim contabilizadas pela polícia ou pelas manchetes, pode partir não de um homem mau. Ela pode surgir como um modo de emergência de uma experiência trágica da loucura - para relembrar o termo de Michel Foucault (1978) em História da Loucura - em que o sofrimento se inscreve como um alto preço a ser pago por um resto de barbárie irredutível ao discurso violento, cujo semblante pode até ser o de um combate à violência. É assim que as rugas da face que narrariam histórias podem ser sobrepostas pelo rosto carrancudo da guerra, realizando os anseios de Ricardo, Duque de Glócester.

\section{Nota:}

1. Trabalho parcialmente apresentado no VIII Congresso Internacional de Psicopatologia Fundamental (Rio de Janeiro - 2018). Pesquisa realizada junto ao GT Reconfigurações do Imaginário no Século XXI - Coordenação de Tania Coelho dos Santos.

\section{Referências Bibliográficas}

Agamben, G. (2015). Meios sem fim - Notas sobre a política. Belo Horizonte: Autêntica Editora. Foucault, M. (1979). História da sexualidade $I-A$ vontade de saber. $2^{\text {aed. }}$ Rio de Janeiro: Edições 
Graal.

Foucault, M. (1978). História da Loucura da Idade Clássica. São Paulo: Editora Perspectiva.

Freud, S. (2012). Totem e Tabu. In: Paulo César de Souza (Trad) Obras completas (vol 11, pp 13244). São Paulo: Companhia das Letras. (Trabalho original publicado em 1912-1913).

Freud, S. (2010). Por que a guerra? (Carta a Einstein, 1932). In: Paulo César de Souza (Trad) Obras completas (vol 18, pp 417-435). São Paulo: Companhia das Letras. (Trabalho original publicado em 1932).

Gay, P. (1995). O cultivo do ódio - A experiência burguesa da Rainha Vitória a Freud. São Paulo: Companhia das Letras.

Marx, K. (2017). Os despossuídos. São Paulo: Boitempo Editorial.

Ribeiro, R. J. (2004). Ao leitor sem medo - Hobbes escrevendo contra seu tempo. Belo Horizonte: Editora UFMG.

Shakespeare, W. (1995). Ricardo III. In Obras completas de Willian Shakespeare (vol 3, pp 575658). Rio de Janeiro: Editora Nova Aguilar S.A.

Shakespeare, W. (1995). Otelo, o Mouro de Veneza. In Obras completas de Willian Shakespeare (vol 1, pp 705-788). Rio de Janeiro: Editora Nova Aguilar S.A.

Citacão/Citation: Andrade, C. (mai. 2018 a out. 2018). O rosto carrancudo da guerra tem as rugas suavizadas. Revista aSEPHallus de Orientação Lacaniana, 13(26), 150-159. Disponível em www.isepol.com/asephallus. Doi: 10.17852/1809-709x.2019v13n26p150-159.

Editor do artigo: Tania Coelho dos Santos.

Recebido/Received: 03/01/2019 / 01/03/2019.

Aceito/Accepted: 12/03/2019 / 03/12/2019.

Copyright: (C) 2019 Associação Núcleo Sephora de Pesquisa sobre o moderno e o contemporâneo. Este é um artigo de livre acesso, que permite uso irrestrito, distribuição e reprodução em qualquer meio, desde que o autor e a fonte sejam citados/This is an open-access article, which permites unrestricted use, distribution, and reproduction in any medium, provided the author and source are credited. 